\title{
Does Regional Economic Performance Affect Bank Conditions? New Analysis of an Old Question
}

\author{
Mary Daly, John Krainer, and Jose A. Lopez \\ Federal Reserve Bank of San Francisco \\ Economic Research Department \\ 101 Market Street \\ San Francisco, CA 94105
}

Draft date: November 28, 2003

\begin{abstract}
The idea that regional economic performance affects bank health is intuitive and broadly consistent with the aggregate banking data. That said, micro-level research on this relationship provides a mixed picture of the importance, size, and timing of regional variables for bank performance. This paper helps reconcile the heterogeneous findings of previous research by: (1) employing a unique "composite measure" of regional economic performance that combines several regional indicators into a single index; (2) constructing bank-specific measures of regional economic conditions, based on bank deposit shares, that account for banks' presence in several states; and (3) estimating models for all banks and intra- and interstate banks separately. Empirical results based on this bank-specific composite regional measure point to a tractable link between regional economic performance and bank health. The importance of regional variables holds for both intra- and inter-state banks. Out-ofsample forecasts indicate that the composite index also helps tie down the relative riskiness of bank portfolios across states. Finally, although interstate banks do seem to diversify away some of their portfolio risk, our analysis suggests it is too soon to conclude that interstate banks are immune from regional influences.
\end{abstract}

Acknowledgments: The views expressed in this paper are those of the authors and not necessarily those of the Federal Reserve Bank of San Francisco or the Federal Reserve System. We thank seminar participants at the Conference on the Use of Composite Indices in Regional Economic Analysis, the Federal Reserve System Conferences on banking studies and regional studies, and Fred Furlong, Andy Haughwout, Leonard Nakamura, Marc Saidenberg, James Stock, and Rob Valletta for helpful comments. We thank Liz Laderman for sharing the summary of deposits data with us, Anita Todd for editorial assistance, and Jackie Yuen and Ashley Maurier for excellent research assistance. 


\title{
Does Regional Economic Performance Affect Bank Conditions? New Analysis of an Old Question
}

Draft date: November 28, 2003

\begin{abstract}
The idea that regional economic performance affects bank health is intuitive and broadly consistent with the aggregate banking data. That said, micro-level research on this relationship provides a mixed picture of the importance, size, and timing of regional variables for bank performance. This paper helps reconcile the heterogeneous findings of previous research by: (1) employing a unique "composite measure" of regional economic performance that combines several regional indicators into a single index; (2) constructing bank-specific measures of regional economic conditions, based on bank deposit shares, that account for banks' presence in several states; and (3) estimating models for all banks and intra- and interstate banks separately. Empirical results based on this bank-specific composite regional measure point to a tractable link between regional economic performance and bank health. The importance of regional variables holds for both intra- and inter-state banks. Out-ofsample forecasts indicate that the composite index also helps tie down the relative riskiness of bank portfolios across states. Finally, although interstate banks do seem to diversify away some of their portfolio risk, our analysis suggests it is too soon to conclude that interstate banks are immune from regional influences.
\end{abstract}




\section{Does Regional Economic Performance Affect Bank Conditions? New Analysis of an Old Question}

\section{Introduction}

The idea that regional economic performance affects bank condition is intuitive and easy to see in the banking data. As Figures 1 and 2 suggest, even regions in close proximity to one another display quite different time-series behavior in standard measures of both bank asset quality and bank performance. Moreover, comparisons of state output growth and movements in non-performing loans suggest a relationship between bank health and regional economic conditions (Figure 3). Despite these patterns in the data, establishing the precise nature of the relationship between bank health and regional economic conditions has proven difficult. Overall, the literature on this issue provides a mixed picture of the importance, size, and timing of regional indicators in models of bank conditions.

The heterogeneity of the empirical results reflects, in part, variation in measures of regional economic performance, differences in model specification, and dissimilarities in the time-periods of study. In terms of variable selection, researchers examining the relationship between regional variables and bank condition have looked for regional measures with the same frequency as the banking data—meaning monthly or quarterly regional indicators. This has limited the set of potential regional indicators to components of gross state product (GSP), the Gross Domestic Product (GDP) analog for states. For instance, researchers have used one or more variables such as employment growth, personal income growth, and commercial and residential real estate values, entering these variables contemporaneously, as lagged values, and as forecasts. Model specifications also vary in whether variables are entered as levels, 
changes, or deviations of both of these from a national mean. By and large, each of these specifications yields different results, especially in terms of the economic importance of regional indicators in models of bank health.

Along with differences in variable selection and model specification, heterogenous results have come from differences in the time periods under study. Figure 4 illustrates why the choice of the analysis period might matter; the figure plots the yearly correlations between state output growth and bank non-performing loans as a fraction of total loans. Abstracting from the volatility in the series, the data show more co-movement between the series during the 1980s than during the 1990s, with especially high negative correlations from 1983 through 1988. The pattern in Figure 4 suggests that the heterogenous results produced by researchers relating economic performance to bank conditions may reflect changes in the dynamics of these relationships, with the interaction of regional economies and bank conditions varying across states and changing over time. ${ }^{1}$

The failing of any single regional indicator or component of GSP is understandable. For one, national economic downturns may materialize differently across states, reflecting differences in sectoral composition, dependence on foreign trade, and interstate linkages. As such, the importance of sectoral indicators—for example, commercial and residential real estate activity, industrial production, exports, and interstate trade flows—-will differ, possibly netting out in aggregate estimates across U.S. states. The contribution of more general measures of regional economic strength, such as employment growth, can also vary

${ }^{1}$ Later in the paper we show that the decreased correlation between state output growth and state non-performing loan ratios owes to convergence across states in both variables. 
substantially across states

depending on worker productivity. ${ }^{2}$ In states with relatively high output per worker, employment growth may lag while output growth exceeds that of other states. In such cases, the employment growth variable would be clouded and possibly fail to correlated in bank condition. These measures also can change over time. For example during the early 1990s, commercial real estate conditions negatively influenced bank performance, while in the recent downturn, commercial real estate portfolios have so far placed little stress on banks. Again, even more general indicators like employment growth may vary in importance over time as growth in productivity fluctuates.

This paper contributes to the literature on regional indicators and bank performance by addressing several of the issues described above. First, it introduces a unique measure of regional economic activity that combines a number of individual regional variables into a single index that is allowed to vary by state. The composite index, or index of coincident indicators, is potentially helpful in two ways. For one, it closely matches real GSP, which is considered a good measure of overall performance of a state's economy. However, unlike GSP, which is produced with a substantial lag and at an annual frequency, the composite index can be produced at the same frequency as our banking data and maintained contemporaneously. In addition to tracking state output growth, the composite index also captures the interactions between independently entered variables such as employment growth and personal income, allowing these interactions to vary across states. Simply stated, it

${ }^{2}$ Wilson (2002) finds pronounced differences in productivity by state over the past two decades. Daly (2002) shows that productivity growth trends were quite different across states in the U.S. over the past two decades. 
proxies for a set of state-level economic "unobservables" that may be affecting the credit quality of bank loan portfolios as measured by nonperforming loans.

Using the composite measure of regional economic conditions, this paper examines the extent to which regional economic conditions help to explain measures of bank-level asset quality. We find that the composite index does help explain bank conditions. The analysis then turns to examining whether the composite index improves forecasts of relative risk of the banking sector by state. These results show that the composite index is helpful in forecasting differences in bank risk by state. Finally, we examine whether interstate banking makes the inclusion of regional variables unimportant. Our findings suggest that such a conclusion cannot be drawn from the existing data.

\section{Literature review}

While it is intuitive that local economic conditions should affect bank health and performance, a large literature on the topic has shown the empirical relationship to be elusive. ${ }^{3}$ On the positive side, Calomiris and Mason (2000) found that several county-level and statelevel economic indicators impacted bank survival rates during the Great Depression. In a more current setting, Avery and Gordy (1998) found that one-half of the change in bank loan performance between 1984-1995 could be explained with a collection of state-level economic variables. Berger, et al. (2000) found evidence that aggregate state-level and regional-level

\footnotetext{
${ }^{3}$ The term "local" economic conditions refers broadly to the county or state in which a bank is headquartered. For this study, the economic variables summarizing local economic conditions will be at the state level, but it is still reasonable to assume that they capture national developments. Specifically, Carlino and DeFina $(1998,1999)$ found that regions, such as New England and the Southeast, and states exhibit different degrees of sensitivity to monetary policy changes.
} 
variables were important contributors to the persistence in firm-level performance (i.e., return on assets) observed in the U.S. banking industry.

But by and large, the statistical link between local economic variables and bank condition fades away when a) economic variables are disaggregated to common local banking market definitions, and b) when the variables are used for forecasting purposes. Zimmerman (1996) and Meyer and Yeager (2001) provide evidence on this first point. Both papers focused on the performance of small banks in the hopes of identifying institutions that would be most vulnerable to economic shocks (i.e., least able to diversify) and could easily be linked to a distinct local economy. Zimmerman looked at the performance of California community banks and found that banks operating in southern California performed significantly worse than their counterparts in northern California between 1990-1994. But he could not find a local economic variable to explain these differences. Meyer and Yeager examined the impact of county-level and state-level economic variables on various bank performance ratios. ${ }^{4}$ They found that the state-level variables significantly impacted bank performance and that countylevel variables did also, but only in the absence of the state-level variables.

In terms of forecasting, Nuxoll, O’Keefe and Samolyk (2003) used economic variables aggregated up to the state level, such as the unemployment rate, growth in personal income,

\footnotetext{
${ }^{4}$ The authors limited their bank sample to small rural banks (i.e., those with less than $\$ 300$ million in assets located outside of a metropolitan statistical area) in the Eighth District of the Federal Reserve System. The four bank performance ratios that they examined were the ratio of nonperforming loans to total loans, the ratio of net loan losses to total loans, the ratio of other real estate owned to total assets, and adjusted return on assets (i.e., net income plus provisions divided by total assets). The county and state variables used were unemployment rates, employment growth, personal income growth, and per capita personal income growth. Note that they used a Tobit regression for the first and third bank variables.
} 
and the amount of failed business liabilities, in order to predict bank failures and bank asset quality. Their basic result was that economic variables add little information to the forecasts of these bank-specific variables. Jordan and Rosengren (2001) investigated whether forecasts of regional economic variables had an impact on the supervisory CAMELS ratings assigned to banks. ${ }^{5}$ They found that contemporaneous measures of regional economic conditions did not add explanatory information over the bank-specific variables already used in bank surveillance models. However, one-year-ahead forecasts were found to be both economically and statistically significant in improving the predictive power of the surveillance models that assess bank performance out four quarters. Furthermore, they found that these effects were more pronounced during difficult regional economic periods.

An important caveat to this analysis and to our data set is that bank deregulation in the U.S. has led to consolidation and to banks' geographic expansion. ${ }^{6}$ As noted by Morgan and Samolyk (2003) in their study of bank geographic diversification, U.S. banks have not only become bigger during the course of the 1990s, but they have also become wider by expanding their operations across multiple banking markets. Using a geographic diversification index based on deposits, the authors found important differences across bank size categories and

\footnotetext{
${ }^{5}$ Their dependent variable reflecting bank performance is the supervisory CAMELS ratings. The bank-specific variables included in their regressions were the logarithm of total assets, lagged CAMELS ratings, the ratio of capital to total assets, the ratio of nonperforming loans to total assets, the ratio of net income to total assets, the ratio of liquid assets to total assets, the ratio of C\&I lending to total assets, the ratio of CRE lending to total assets, the ratio of residential real estate lending to total assets, the ratio of other real estate owned to total assets, the ratio of long-term deposits to total assets, and the ratio of thirty-day past-due loans to total assets. The state-level regional economic variables they used were payroll employment growth, residential house price appreciation, and total personal income growth.

${ }^{6}$ See the papers by Jayaratne and Strahan (1996) and Morgan, Rime, and Strahan (2002) for research on the impact of banking deregulation on local economic variables.
} 
over time. We address this concern only in terms of constructing the regional variables corresponding to the inter-state banks in our sample; see the discussion in the following section.

\section{Data and Measurement Issues}

\section{Regional Composite Indicators}

Tracking the health of regional economies has long been a difficult job. Analogs to traditional measures of national economic performance such as GSP (GDP analog) are produced with a significant lag and only at an annual frequency, limiting their usefulness for most research endeavors. Other measures of performance including employment growth, commercial and residential building permits, or personal income growth, while more current, are less complete, capturing only a part of the picture of economic activity in a region. The incompleteness of single measures of economic activity is well recognized (Zarnowitz, 1992), prompting the NBER to look across many series to date business cycles (Rudebusch, 2001).

Building on the work by Stock and Watson (1989) who develop a coincident index for the national economy, Crone (1994) began developing composite indices of regional economic activity. ${ }^{7}$ The indices produced proved useful for tracking regional economic trends and for dating regional business cycles (Crone (1999)). In 2002, Crone produced a set of consistent economic indexes for the 50 states. ${ }^{8}$ The indexes are produced at a monthly

${ }^{7}$ Crone originally constructed his indices for states based on four monthly data series- the total number of jobs in nonagricultural establishments, real retail sales, average weekly hours in manufacturing, and the unemployment rate.

${ }^{8}$ These series have been made publicly available by the Federal Reserve Bank of Philadelphia. 
frequency and cover the period from 1978 through 2002.

As constructed by Crone (2002) the coincident indexes for the 50 states include three monthly indicators-nonagricultural employment, the unemployment rate, and average hours worked in manufacturing — and one quarterly indicator—real wage and salary disbursements—of regional economic conditions. To ensure consistency, Crone applies the following criteria:

(1) The indexes are constructed from the same set of indicators for each state

(2) The timing of the index is benchmarked to employment in each state.

(3) The trend for the index corresponds to (GSP) in each state.

Figure 5 shows a scatter plot of average annual growth between 1986 and 2000 in GSP and the composite indicator growth for the 50 states. The composite indicators for each state are aggregated to the annual frequency for comparison with GSP. As the figure shows, the composite indicator tracks GSP quite well.

\section{Other Regional Indicators}

By and large, the literature on bank performance and regional economic conditions has relied on one or more regional indicators including house price appreciation, employment growth, personal income growth, and the unemployment rate. To tie this paper to previous work in the area and to evaluate the usefulness of composite measures relative to others, these variables are included in the analyses. House price appreciation by state is measured using data from the Office of Federal Housing Enterprise Oversight (OFHEO). OFHEO produces an index of home prices by state on a quarterly basis. These indices are used to compute yearover-year growth rates for house prices in each state. The personal income data come from 
the Bureau of Economic Analysis and are released quarterly. Again, the quarterly levels are used to compute year-over-year growth rates. Data on employment and unemployment come from the Bureau of Labor Statistics. The data are released monthly. The analysis includes year-over-year changes in these variables at a quarterly frequency.

\section{Bank-Specific Regional Indicators}

A key challenge in this analysis is the problem of correctly identifying the regional economy for an individual bank. An obvious choice is to simply define the state of headquarters as the bank's region. Such a choice was accurate before the advent of cross-state banking laws in the early 1980s and the Riegle-Neal Act of 1994 that opened up the entire country to bank branches, and is probably still reasonable for the case of small banks (see Meyer and Yeager (2001)). For the sample used in this analysis, however, a more complete measure of banks' regions is required.

For this paper, a bank's regional economy is defined as a weighted average of the states it operates in; the weight on any given state corresponds to the share of the bank's total deposits that originate from that state. The bank-specific weights are constructed based on the branch-level data available from the Summary of Deposits (SOD) data collected and maintained by the Federal Deposit Insurance Corporation (FDIC). ${ }^{9}$ The SOD database contains deposit data for more than 85,000 branches/offices of FDIC-insured institutions. SOD information is required for each insured office located in any state, the District of

${ }^{9}$ Further information on and access to the SOD data is available at http://www2.fdic.gov/sod/index.asp. 
Columbia, the Commonwealth of Puerto Rico or any U.S. territory or possession such as Guam or the U.S. Virgin Islands, without regard to the location of the main office. For SOD purposes, a branch/office is any location, or facility, of a financial institution, including its main office, where deposit accounts are opened, deposits are accepted, checks paid, and loans granted. Some branches include, but are not limited to, brick and mortar locations, detached or attached drive-in facilities, seasonal offices, offices on military bases or government installations, paying/receiving stations or units, and Internet and PhoneBanking locations where a customer can open accounts, make deposits, and borrow money. This definition of a branch should very accurately gauge the cross-state activities of a bank. ${ }^{10}$

All the regional variables and the composite index are weighted by the deposit shares to define bank-specific regional economic conditions. Data are collected annually, hence the bank-specific weights are only updated once every four quarters.

\section{Banking Variables}

The banking data are collected from the quarterly Reports of Condition (the Call Reports) that commercial banks file with their bank regulators. The data set consists of all commercial banks with domestic charters between 1983.Q3 and 2002.Q3. As is welldocumented in the literature, changes in regulation and competitive pressures spurred a remarkable degree of consolidation in the banking industry. These changes are apparent in the

\footnotetext{
${ }^{10}$ For SOD purposes, the FDIC collects deposit balances for commercial and savings banks as of June 30 each year. For insured commercial banks and FDIC-supervised savings banks, the definition of deposit is the same as in the Consolidated Report of Condition. The definition relates to domestic deposits held, or accepted, by the reporting bank in its main office and in any branch located in any State, the District of Columbia, the Commonwealth of Puerto Rico, or any U.S. territory or possession which include but are not limited to Guam and the U.S. Virgin Islands.
} 
data set used in this paper (see Figure 5). At the beginning of the period there are 13,288 unique bank entities in the banking database; by the end of the sample period, this number had dwindled to 7,620 banks.

Bank condition is measured here as the ratio of total nonperforming loans to total loans, where non-performing loans are defined as all loans past due thirty days or more but still accruing interest and non-accruing loans. Bank-level control variables include the natural $\log$ of assets to control for the many differences between large and small banks, the share of the loan portfolio assigned to commercial and industrial (C\&I) lending, consumer lending, and residential and nonresidential real estate. The banking variables are summarized in Table 1.

\section{Evidence of a Relationship}

Before specifying a model of the relationship between bank conditions and regional economic performance it is useful to pin down their association using simple Granger Causality tests. Specifically, for each state we test whether annual growth in the coincident indicator Granger-causes the state-level of nonperforming loans ratio, and vice versa. Aggregating across states, we also test whether the variance in states' annual growth rates of the coincident indicators Granger-causes the variance across states non-performing loan ratios. We use 8 lags of both the dependent and independent variables in the tests. The results of these tests are reported in Table 2.

The results provide mixed evidence of the importance of regional indicators in predicting bank condition at the state level, with growth in the coincident indicator Grangercausing the nonperforming loan ratio in 12 states. Importantly, there is less evidence that the 
relationship works the other way; nonperforming loan ratios Granger-caused growth in just 5 states.

A much clearer picture emerges for the relationship between the cross-state variance in growth in the coincident indicator and the non-performing loan ratio (final row of Table 2). The variance in annual growth of the coincident indicator across states Granger-causes the variance in non-performing loan ratios across states, but the reverse does not hold. There is no evidence of feedback from nonperforming loans to regional economic growth.

These results suggest a role for regional indicators in models of bank condition, especially in modeling differences across states over time. Based on these findings we turn to estimating a reduced form model of bank performance that includes bank specific variables and regional economic conditions.

\section{In-Sample Importance of Regional Variables}

\section{The Model}

By and large, the literature on the impact of regional economic performance on bank conditions relies on a basic model specification that regresses individual bank condition variable on a set of bank-specific variables and regional indicators. This type of model is followed in this paper. ${ }^{11}$ The estimated model takes the following form:

$$
y_{i j t}=\alpha+\beta x_{i t-4}+\theta z_{j t-4}+\varepsilon_{i j t},
$$

\footnotetext{
${ }^{11}$ An alternative specification would be to do the estimation in two stages, in which the first stage
} regresses bank nonperforming loans on bank-specific variables and 50 state dummies for each quarter, and the second stage regresses the state dummies on regional economic indicators (Card and Krueger 1992; Hanushek, Rivkin, and Taylor 1996). The model in equation (1) was chosen to be consistent with the previous literature and to permit interactions between bank-specific variables and regional indicators. 
where $\mathrm{y}_{i j t}$ is the nonperforming loan ratio for bank $I$ operating in region $j$ at time $t, \alpha_{i}$ is the intercept term, $x_{i}$ is a vector of bank-specific variables, and $z_{j}$ is a vector of region-specific variables, including the composite index. The explanatory variables are lagged four quarters under the assumption that changes in bank characteristics and regional economic condition will take several quarters to appear in the performance or asset quality variables. All regressions are estimated with state dummies and robust standard errors to account for the non-independence of multiple observations on the same bank over time. The regression results are reported in Tables 3-5. Note that the five specifications of the model used throughout the paper are: (I) bank-specific variables only; (ii) bank-specific variables plus regional variables excluding the composite index; (iii) bank-specific variables and all regional variables; (iv) bank-specific variables and just the composite index; and (v) all the prior variables plus the composite index interacted with the bank's portfolio shares.

\section{All Banks}

The results for all banks are reported in Table 3. The findings point to a strong impact associated with the inclusion of the lagged value of the nonperforming loan ratio in all of the specifications. Invariably, the coefficient on the lagged dependent variable is approximately 0.66 and is statistically significant. In addition, including this variable in the specification increases the regression $R^{2}$ from approximately $4 \%$ to $50 \%$ in most of our regressions. Also, consistent with many other studies in banking, the size control is statistically significant. Larger banks tend to have lower nonperforming loan ratios than smaller banks.

The inclusion of economic variables yields somewhat promising results (column 2 of Table 3). However, the counterintuitive sign on personal income growth is an example of 
some of the difficulties researchers have had in pinning down the influence of regional economic conditions on bank condition. We would expect positive changes in this variable to be associated with decreasing problem loan ratios, all else being held equal. Overall, the coefficients on the change in house prices and the employment variables all have the predicted signs and are statistically significant.

In column 3 of Table 3, the composite index is added to the model along with the other regional variables. All coefficients on the observable economic variables remain statistically significant, although their magnitudes are somewhat diminished when the composite index is included. This is particularly true for the employment growth variable, which declines in importance by an order of magnitude. The coefficient on the year-over-year change in the composite index, meanwhile, is estimated to be -0.046 , which has the largest magnitude of any of the coefficients on economic variables. A more parsimonious specification that drops all the observable economic series and includes only the control variables and the composite index is shown in column 4 of the table. Again, the estimated coefficient on the composite index is sizeable (-0.044) and statistically significant at the conventional levels.

The final column of Table 3 shows a specification of the model that includes interactions with the bank's loan portfolio. The interaction terms are meant to examine whether banks with particular loan concentrations are more/less susceptible to regional shocks. The findings indicate that the largest impact of the composite index is for banks with large concentrations of non-residential real estate and C\&I loans. This result seems consistent with both the greater volatility in the commercial sectors and the ability of banks to more 
easily diversify their risk on residential and consumer loans. ${ }^{12}$

\section{Intrastate and Interstate Banks}

Given the national deregulation of interstate banking that occurred during the 1990s, we chose to extend the analysis by examining inter- and intrastate banks separately. The results are presented in Tables 4 and 5. The separate analysis focuses on whether banks that eventually become interstate banks differ from those that remain intrastate banks. The composite index as the sole economic variable, the coefficient on the composite index is virtually the same across interstate and intrastate banks.

That said, there is an interesting difference between the intrastate and interstate regressions. The interactions between loan shares and the composite index are insignificant in the interstate regressions. This contrasts with the intrastate regressions where the effect of the composite index on nonperforming loans was significantly greater for banks with relatively large commercial real estate and commercial lending portfolios. This finding suggests that the geographic diversification by interstate banks may translate into diversification of risk on all loans, not just residential and consumer.

\section{In-Sample Results Summary}

The results from our reduced form models point to a clear link between regional indicators and bank performance. The linkage appears most robust for the composite index measure of regional economic performance. This is consistent with other work showing positive and consistent results for GSP variables and more mixed results for other regional

${ }^{12}$ The Table 3 analysis was repeated including bank fixed effects. Except the growth in personal income, all coefficients on the economic variables have the same expected signs and are statistically significant at conventional levels. Results are available from the authors upon request. 
indicators. The results from the inter- and intrastate banks suggest that regional conditions are important explanatory factors for both types of entities, although interstate banks appear more able to diversify away portfolio risk more than intrastate banks.

\section{Out-of-Sample Importance of Regional Variables}

The in-sample results point to the usefulness of regional indicators for explaining bank condition. A next logical step is to see whether such regional indicators could help in forecasting bank conditions out-of-sample. Previous attempts to forecast bank performance using regional economic variables have been unsuccessful, as discussed in the literature review. Similar calculations based on our dataset also provide little evidence that including regional variables improves the forecasts of individual bank condition.

However, this outcome need not imply that regional variables cannot be used to understand broader trends in banking sector conditions. To examine this alternative perspective, we focus on forecasting the relative rankings of bank risk, measured as nonperforming loan ratios, by state. Such rankings are useful to both bankers, who are potentially managing loans to borrowers across the country, and to bank supervisors, who monitor the condition of banks nationwide. Although these rankings abstract from the absolute level of bank risk, they retain a useful amount of relative risk information at a point in time and across time.

Our forecasting exercise proceeds as follows. First, we modify the modeling framework from the earlier part of the paper and estimate a linear probability model of 
whether or not a bank's problem loan category exceeds a predetermined level- $5.4 \%{ }^{13}$

Second, we break the full sample into three subperiods and estimate the models for each subperiod absent the last year. We use the fitted models for each period to forecast the value of the linear probability model for each bank in each period's out-of-sample period; that is, the four quarters of 1989, the four quarters of 1995, and the three quarters of 2002, respectively. We denote the forecasted value for bank I headquartered in state $\mathrm{j}$ at time $\mathrm{t}+1$, conditional on the information available at time $\mathrm{t}$, as $\hat{\mathrm{y}}_{\mathrm{ijt}+1} \cdot{ }^{14}$ Since we are estimating a linear probability model, the actual numerical values of $\hat{\mathrm{y}}_{\mathrm{ijt}+1}$ are not especially meaningful to the analysis. However, the cardinal ordering of these numerical values allows us to generate state-level risk rankings based on nonperforming loan ratios.

To generate state-level ratios of nonperforming loans to total loans, we aggregate across banks in each state at each point in our forecasting periods. That is, the nonperforming loan ratio for state $\mathrm{j}$ at time $\mathrm{t}+1$, denoted as $\widehat{\mathrm{NPL}}_{\mathrm{jt}+1}$, is calculated as

$$
\widehat{\mathrm{NPL}}_{\mathrm{jt}+1}=\sum_{\mathrm{i} \in \mathrm{j}} \hat{\mathrm{y}}_{\mathrm{ijt}+1}\left(\frac{\mathrm{L}_{\mathrm{ijt}+1}}{\mathrm{~L}_{\mathrm{jt}+1}}\right) \text {, }
$$

where $\mathrm{L}_{\mathrm{ijt}+1}$ is the total loans for bank I headquartered in state $\mathrm{j}$ at time $\mathrm{t}+1$ and $\mathrm{L}_{\mathrm{jt+1}}$ is the total

\footnotetext{
${ }^{13}$ The new dependent variable is a binary variable equal to one if the total nonperforming loan ratio is greater than $5.4 \%$. This threshold corresponds to the $80^{\text {th }}$ percentile of the empirical distribution of nonperforming loans in our entire data. sample.

${ }^{14}$ Note that $\hat{y}_{\mathrm{itt}+1}$ is neither an indicator variable, like our dependent variable, nor is it a true probability, since its support is not limited to the unit interval. Instead, $\hat{y}_{\mathrm{ijt}}$ is a relative value that indicates proximity to the $5.4 \%$ nonperforming loan ratio that we selected; that is, higher values of $\hat{\mathrm{y}}_{\mathrm{itt}+1}$ indicate that bank $\mathrm{i}$ is more likely to be above the threshold, while lower values of $\hat{\mathrm{y}}_{\mathrm{ijt} t 1}$ indicate that the bank is more likely to be below the threshold.
} 
loans across all banks headquartered in state $\mathrm{j}$ at time $\mathrm{t}+1$. We construct the actual state problem loan ratios, denoted as $\mathrm{NPL}_{\mathrm{jt+1}}$ using the same formula as above, but replacing the $\hat{y}_{\mathrm{ijt}+1}$ values with the actually observed nonperforming loan ratios for the individual banks. We generate four sets of forecasted state rankings based on the variables specification used in Section V. We assess the accuracy of these forecasted state rankings by examining the extent to which they reproduce the actual rankings of state-level nonperforming loan ratios. The degree of forecast accuracy is measured using the Spearman rank correlation test, which tests the null hypothesis that the actual and the forecasted rankings are independent. If we reject the null hypothesis, then the model generating the forecasts is accurately characterizing the underlying economic relationships. The values of these correlation coefficients are presented in Table 6; note that they are all significant at the 5\% level.

To consider the importance of the regional indicators, we look to see whether the forecasted rankings are different, depending on the inclusion of the composite index in the forecasting model. The findings show that regional variables do improve forecasts of statelevel bank risk, i.e., the coefficients in the fourth column are larger than those in the first column for all 11 out-of-sample forecast quarters. However, the results also highlight the potential difficulties of using a collection of individual regional indicators-employment growth, personal income growth, and home price appreciation. As shown in the second column, in some of the time periods and relative to the baseline model in the first column, the inclusion of these individual regional indicators hinder rather than help the forecast. This is where the composite index clearly dominates the other regional variables in the analysis. By collecting the trend that is common to all included regional indicators it improves the signal to 
noise ratio and aids the forecast accuracy of the state rankings, as shown in the third column. In all the time periods forecast, the composite indicator either improves or fails to change the forecast with the bank variables alone.

\section{Regional Economic Conditions Under Interstate Banking}

Our findings point to a clear link between regional economic conditions and bank condition for both intrastate and interstate banks. That link, however, largely results from variance in state regional growth and loan performance that predates the full expansion of interstate banking; data from the 1980s and early 1990s. This has led some to argue that these linkages may have dissolved. To get at this issue, we ran regressions based on equation (1) on a subsample of the data ranging from 1995.Q1 to 2002.Q3 for both interstate and intrastate banks. ${ }^{15}$ The idea was to examine whether the economic and/or statistical significance of the regional indicators has dissipated for the interstate banks, while remaining important to intrastate banks. The results show that during the latter half of the 1990s none of the regional economic variables (including the composite index) had a statistically significant effect on either intrastate or interstate bank nonperforming loan ratios.

The reason for this non-result can be seen in Figure 7, which shows the variance in regional economic growth (measured by the composite index) and state nonperforming loan ratios. ${ }^{16}$ As the figure indicates, during the latter half of the 1990s, the variance of these two

\footnotetext{
${ }^{15} \mathrm{We}$ do not show results from these regressions, but they are available from the authors upon request.

${ }^{16}$ Another possibility is the relatively short sample period. However, regressions for sample periods of equal length during the 1980s and early 1990s produce statistically significant coefficients on
} 
series dropped dramatically and stayed virtually unchanged for the remainder of the decade. The lack of movement in either series makes hinders our ability to track their underlying relationship.

What can we expect going forward? Without additional data we cannot know whether the 1995-2002 period was an aberration or per the discussion in Stock and Watson (2002) a permanent change in the relationship between bank condition and regional economic performance. Given very recent data, the convergence of regional growth that characterized the late 1990s already is fading as states recover from the recession at varying speeds. Moreover, the variance of the nonperforming loan values has begun to increase, suggesting that its period of stability also may be nearing an end. Finally, earlier results from our Granger causality tests provide little support for the idea that the convergence of banking outcomes portends convergence in regional economic growth.

\section{Conclusion}

In summary, our work points to a clear link between bank conditions, measured by nonperforming loan ratios, and state-level composite indexes and other regional variables. The statistical significance and economic relevance of the composite index remains stable across bank sub-samples (interstate and intrastate). In general, the composite index performs at least as well as employment growth and outperforms other measures of regional conditions. Moreover, it appears to capture important and tractable interactions among the included regional variables that would otherwise be relegated to the state fixed effect or the residual.

the regional variables, suggesting the short sample is not driving our 1995-2002 findings. 
We find that for interstate banks, the composite index is the single-most important explanatory variable from our set of regional economic variables. For intrastate banks, the composite index has the largest impact on those banks specializing in certain types of lending, be it commercial real estate or business lending. This sensitivity to the indicator is not as pronounced for interstate banks, which presumably are better able to diversify risks in their laon portfolios.

Our work also shows that while regional variables do little to improve the forecasts of individual bank performance they are quite useful in forecasting state rankings of relative risk in the banking sector. This is where the composite indicator clearly outperforms the other regional indicators. In all cases tested, the composite indicator either improves or leaves unchanged the forecast accuracy relative to including bank variables alone.

Finally, our analyses provides reason to believe that the advent of interstate banking will not eliminate the importance of looking at regional economic conditions when tracking trends in bank performance. Although the importance of regional variables falls away in the time period following the allowance of interstate banking, our results indicate this likely has more to do with the idiosynchratic convergence of regional growth and bank performance measures than with the advent of interstate banking. 


\section{References}

Avery, R., and Gordy, M., 1998. "Loan Growth, Economic Activity, and Bank Performance." Board of Governors of the Federal Reserve System working paper.

Berger, A.N., Bonime, S.D., Covitz, D.M. and Hancock, D., 2000. "Why are Bank Profits so Persistent? The Roles of Product Market Competition, Informational Opacity and Regional / Macroeconomic Shocks," Journal of Banking and Finance, 24, 1203-1235.

Calomiris, C.W. and Mason, J.R., 2000. "Causes of U.S. Bank Distress During the Depression,” NBER Working Paper \#7919.

Card, D. and A. Krueger, 1992. "School Quality and Black-White Relative Earnings: A Direct Assessment.” The Quarterly Journal of Economics, 107 (1), 151-200.

Carlino, G. and DeFina, R., 1998. "The Differential Regional Effects of Monetary Policy," Review of Economics and Statistics, 80, 572-587.

Carlino, G. and DeFina, R., 1999. “The Differential Regional Effects of Monetary Policy: Evidence from the U.S. States," Journal of Regional Science, 39, 339-358.

Collender, R.N. and Shaffer, S., 2003. "Local Bank Office Ownership, Deposit Control, Market Structure, and Economic Growth," Journal of Banking and Finance, 27, 27-57.

Crone, T.M., 1994. "New Indexes Track the State of the States," Federal Reserve Bank of Philadelphia Business Review, January/February, 19-31.

Crone, T.M., 1999. "Using State Indexes to Define Economic Regions in the United States," Working Paper \#1999-19, Federal Reserve Bank of Philadelphia.

Crone, T.M., 2002. “Consistent Economic Indexes for the 50 States," Working Paper \#200207, Federal Reserve Bank of Philadelphia.

Daly, M.C., 2002. "Riding the IT Wave: Surging Productivity Growth in the West," FRBSF Economic Letter, \#2002-34.

Hanushek, E., S. Rivkin, L. Taylor, 1996. “Aggregation and the Estimated Effects of School Resources." The Review of Economics and Statistics, 78(4), 611-627.

Jayaratne, J. and Strahan, P.E., 1996. "The Finance-Growth Nexus: Evidence from Bank Branch Deregulation," Quarterly Journal of Economics, 111, 639-670.

Jordan, J.S. and Rosengren, E.S., 2001. "Economic Deterioration and Bank Health," 
Manuscript, Federal Reserve Bank of Boston.

Meyer, A.P. and Yeager, T.J., 2001. "Are Small Rural Banks Vulnerable to Local Economic Downturns?," Federal Reserve Bank of St. Louis Review, March/April, 25-38.

Morgan, D.P., Rime, B. and Strahan, P.E., 2002. "Bank Integration and State Business Cycles," Manuscript, Research and Market Analysis Group, Federal Reserve Bank of New York.

Morgan, D.P. and Samolyk, K., 2003. “Geographic Diversification in Banking and its Implications for Bank Portfolio Choice and Performance," Manuscript, Research and Market Analysis Group, Federal Reserve Bank of New York.

Rudebusch, G., 2001. "Has a Recession Already Started?," FRBSF Economic Letter, \#2001-29.

Stock, J.H. and Watson, M.W., 1989. "New Indexes of Coincident and Leading Economic Indicators," NBER Macroeconomics Annual, 351-394.

Wilson, D., 2002. "Productivity in the Twelfth District," FRBSF Economic Letter, \#2002-33.

Zarnowitz, V., 1992. Business Cycles: Theory, History, Indicators and Forecasting. Chicago: University of Chicago Press.

Zimmerman, G., 1995. "Factors Influencing Community Bank Performance in California." Federal Reserve Bank of San Francisco Economic Review. Number 1, 26-42. 
Figure 1. Total past-due to total loans

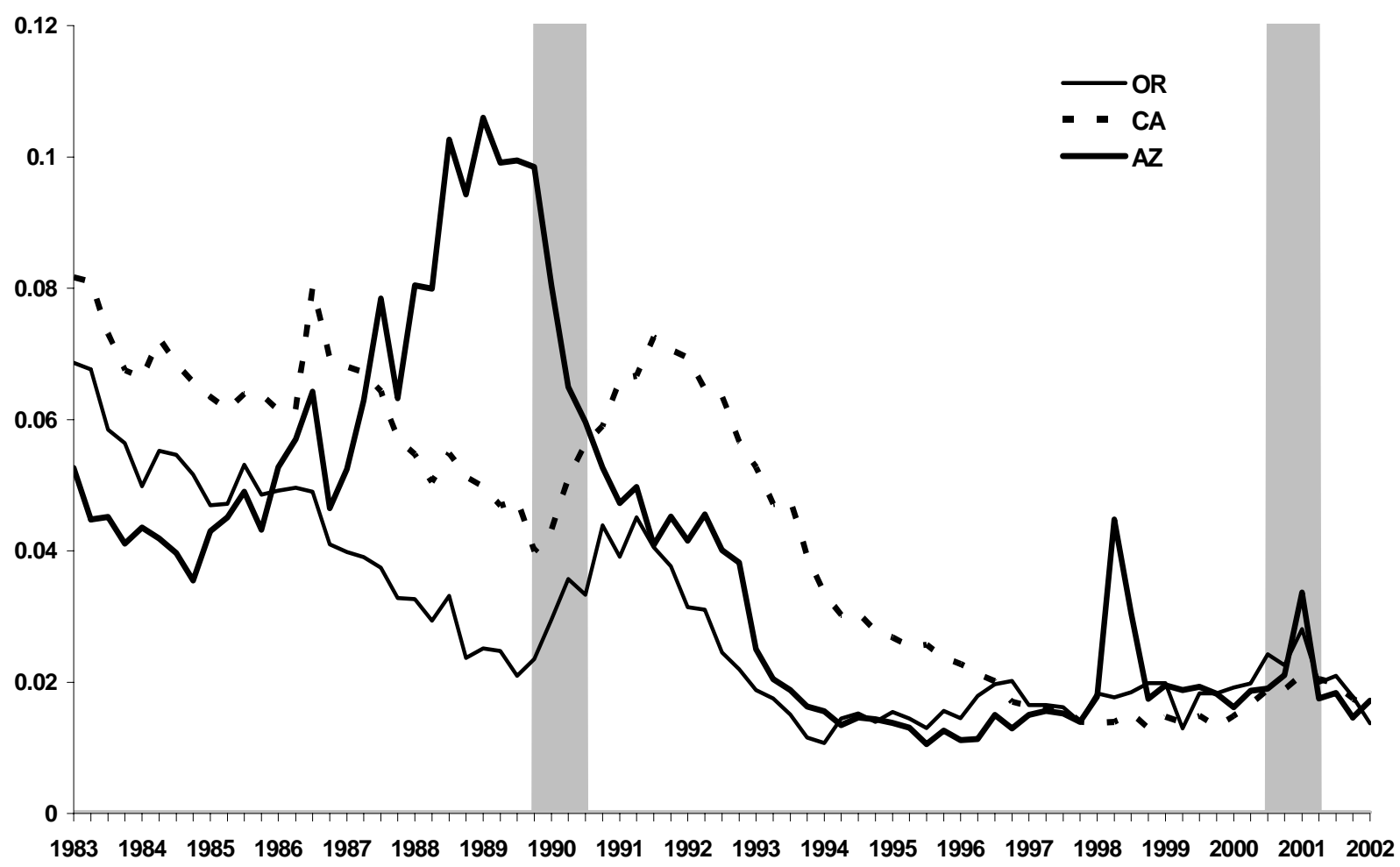

Figure 2. Return on assets

(4-quarter average)

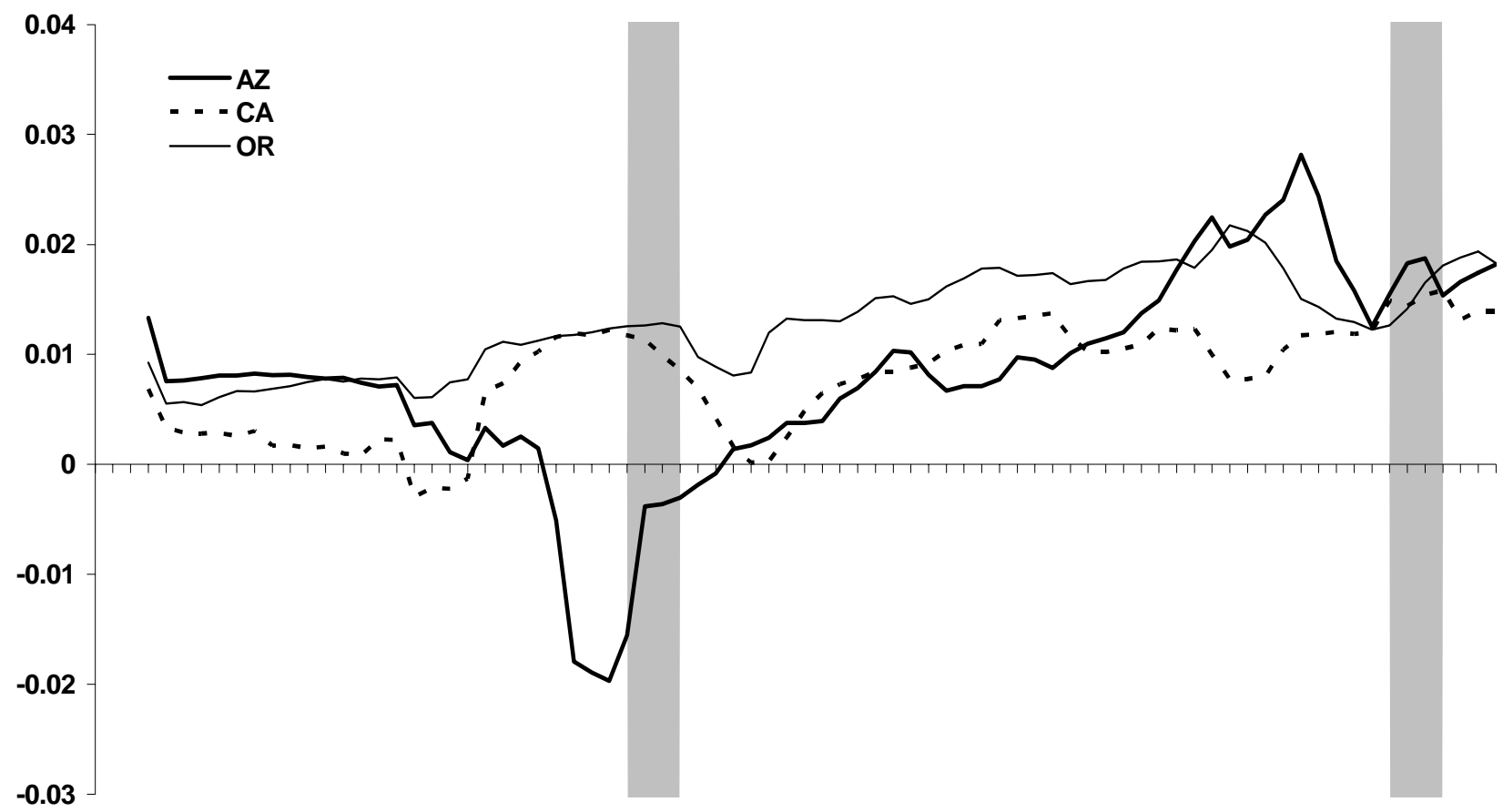

19821983198419851986198719881989199019911992199319941995199619971998199920002001 
Figure 3. Economic Growth and Nonperforming Loans California

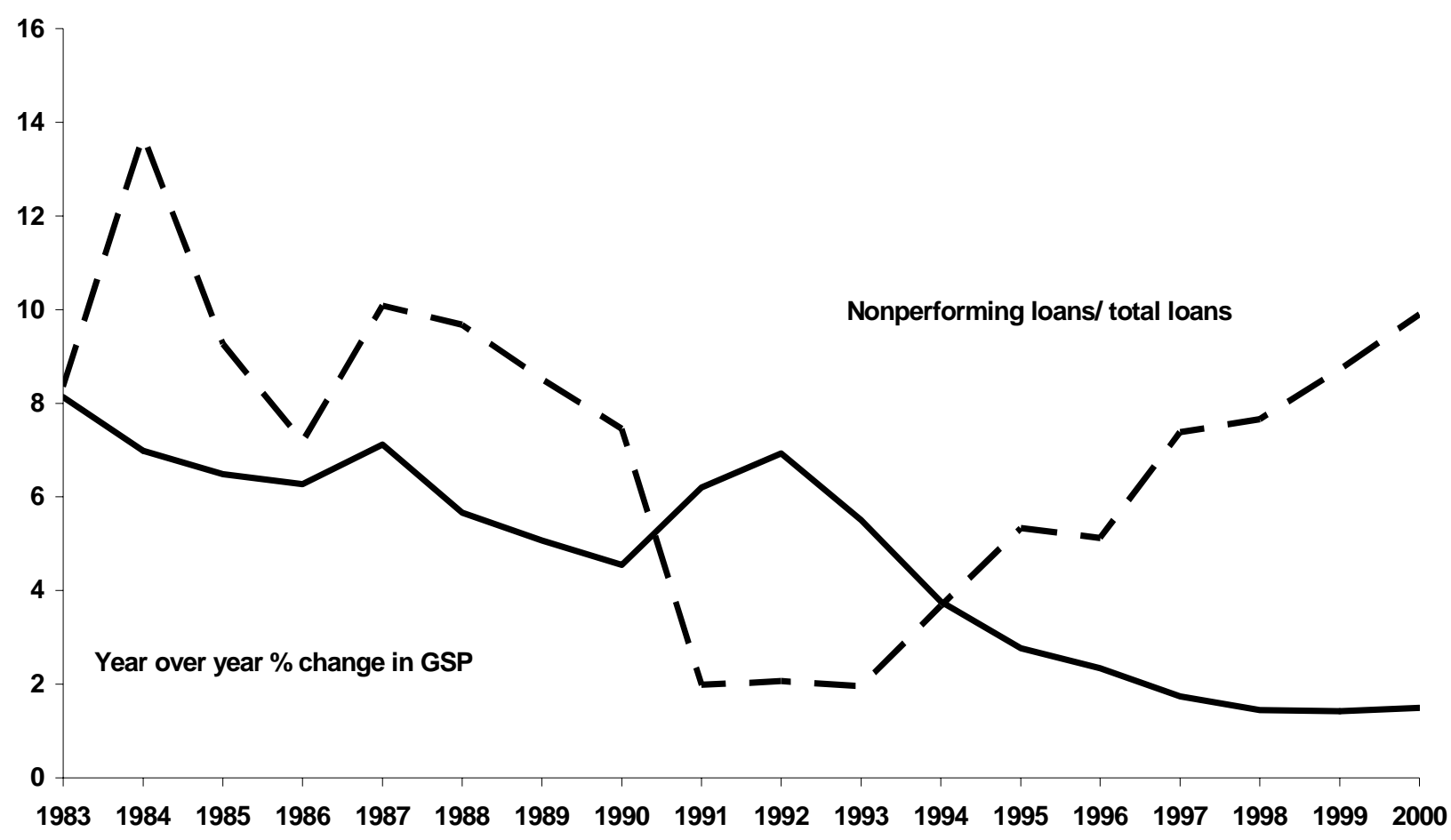

Figure 4. Trends in the Cross-Sectional Correlation Between State Economic Growth (GSP) and Nonperforming Loan Ratios

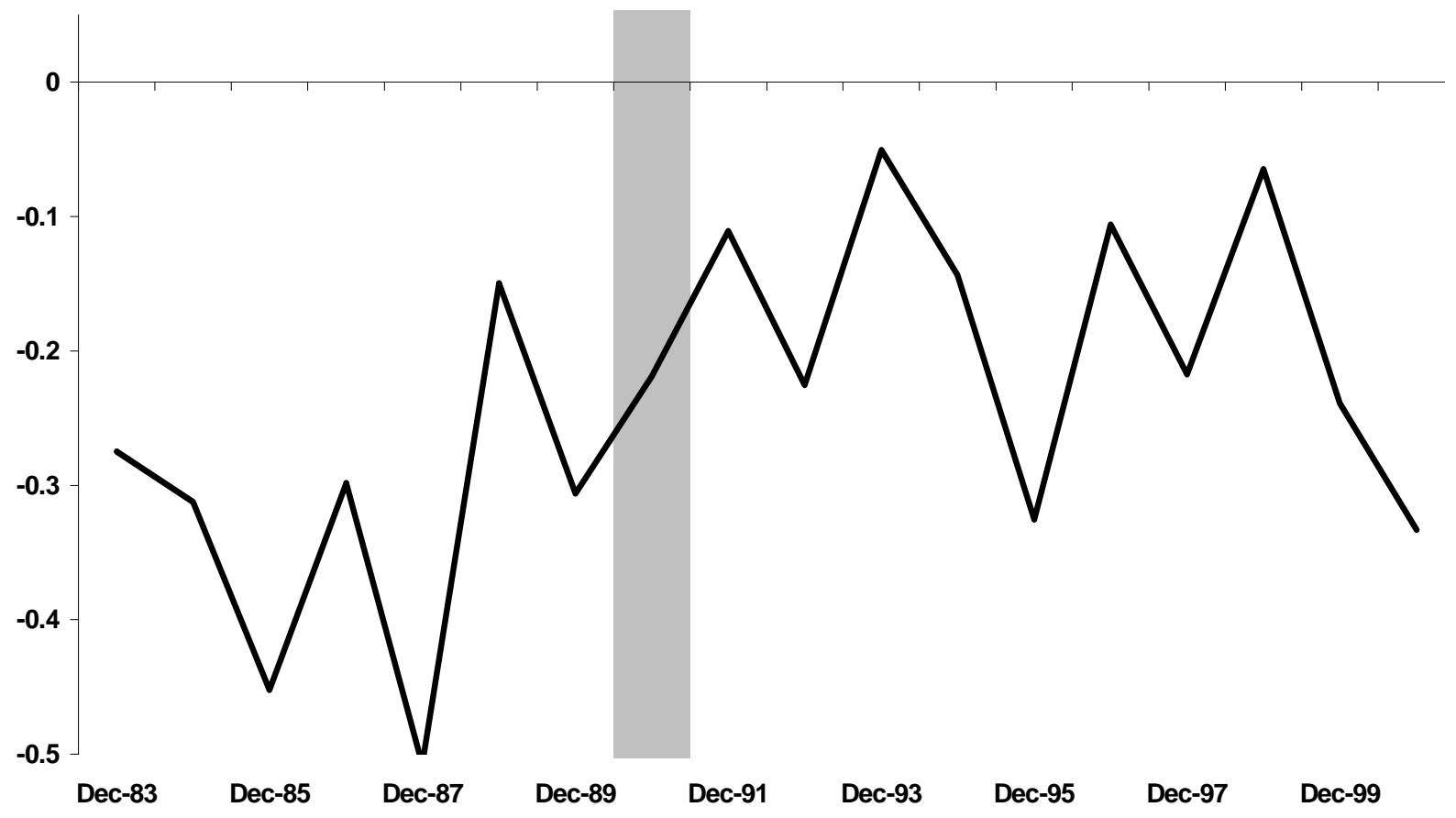


Figure 5. Average annual growth between 1986 - 2000 State GSP and Composite Indicator

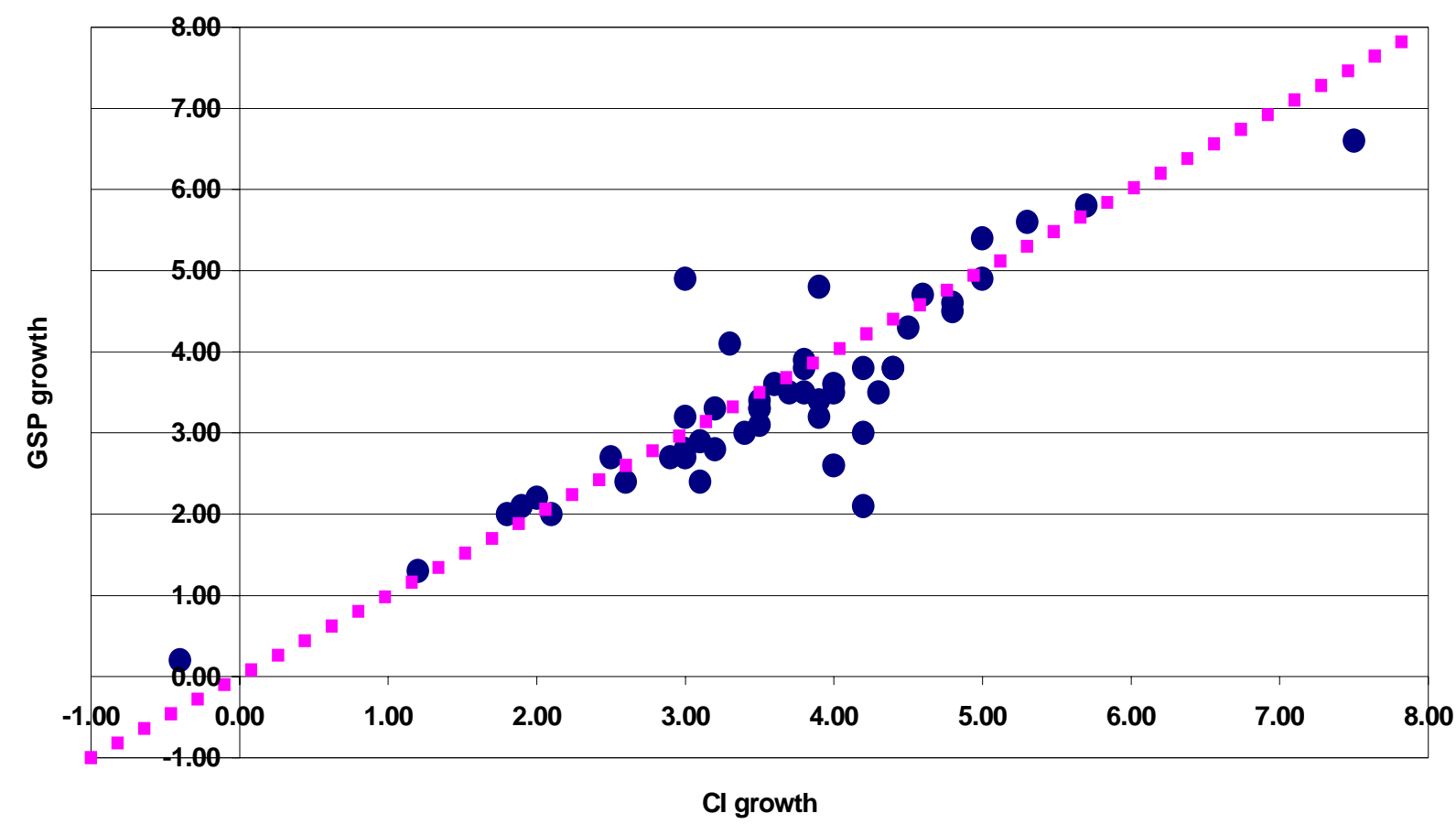

Figure 6. Number of domestically chartered commercial banks

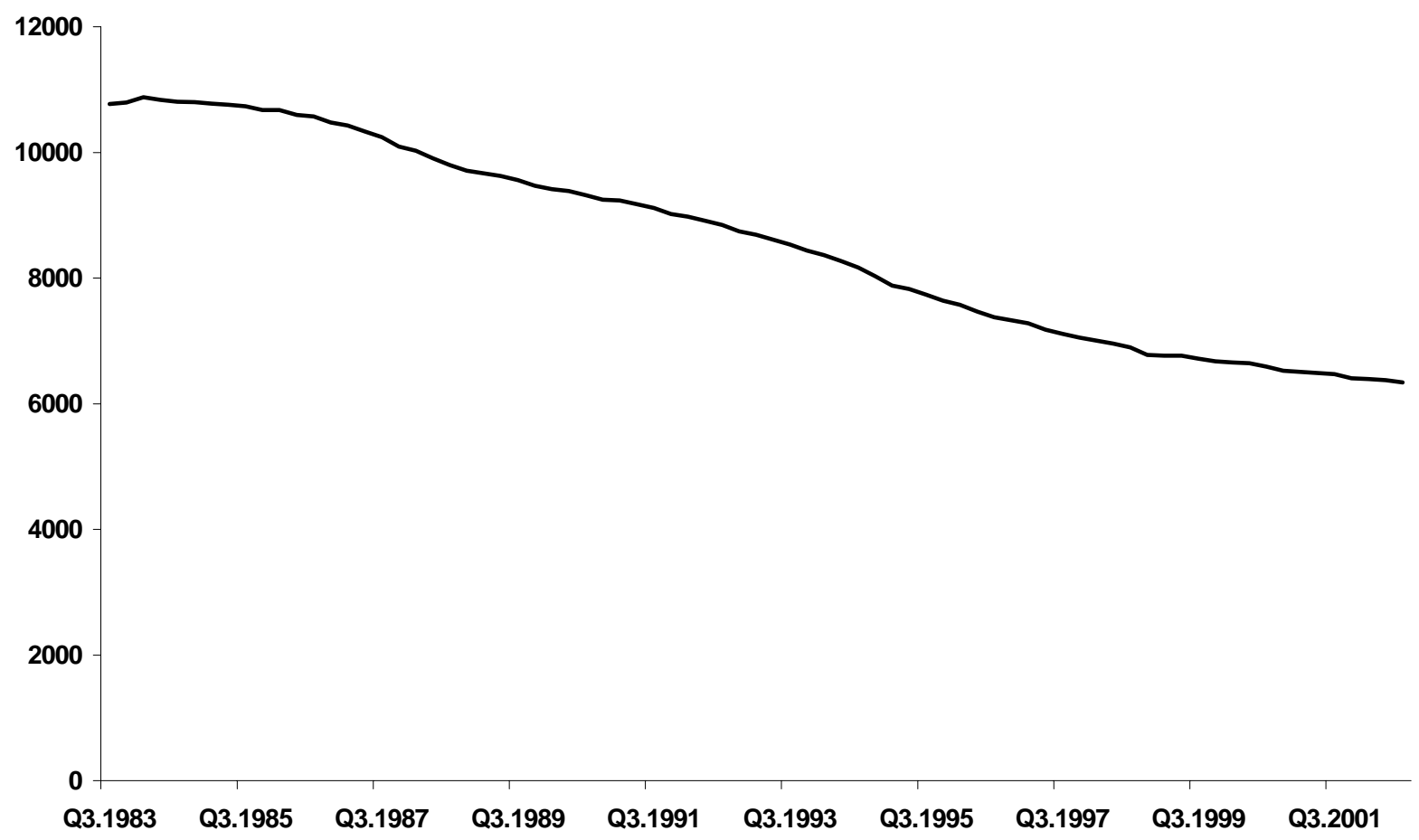


Figure 7. Cross-State Variance in

Economic Growth and Nonperforming Loans

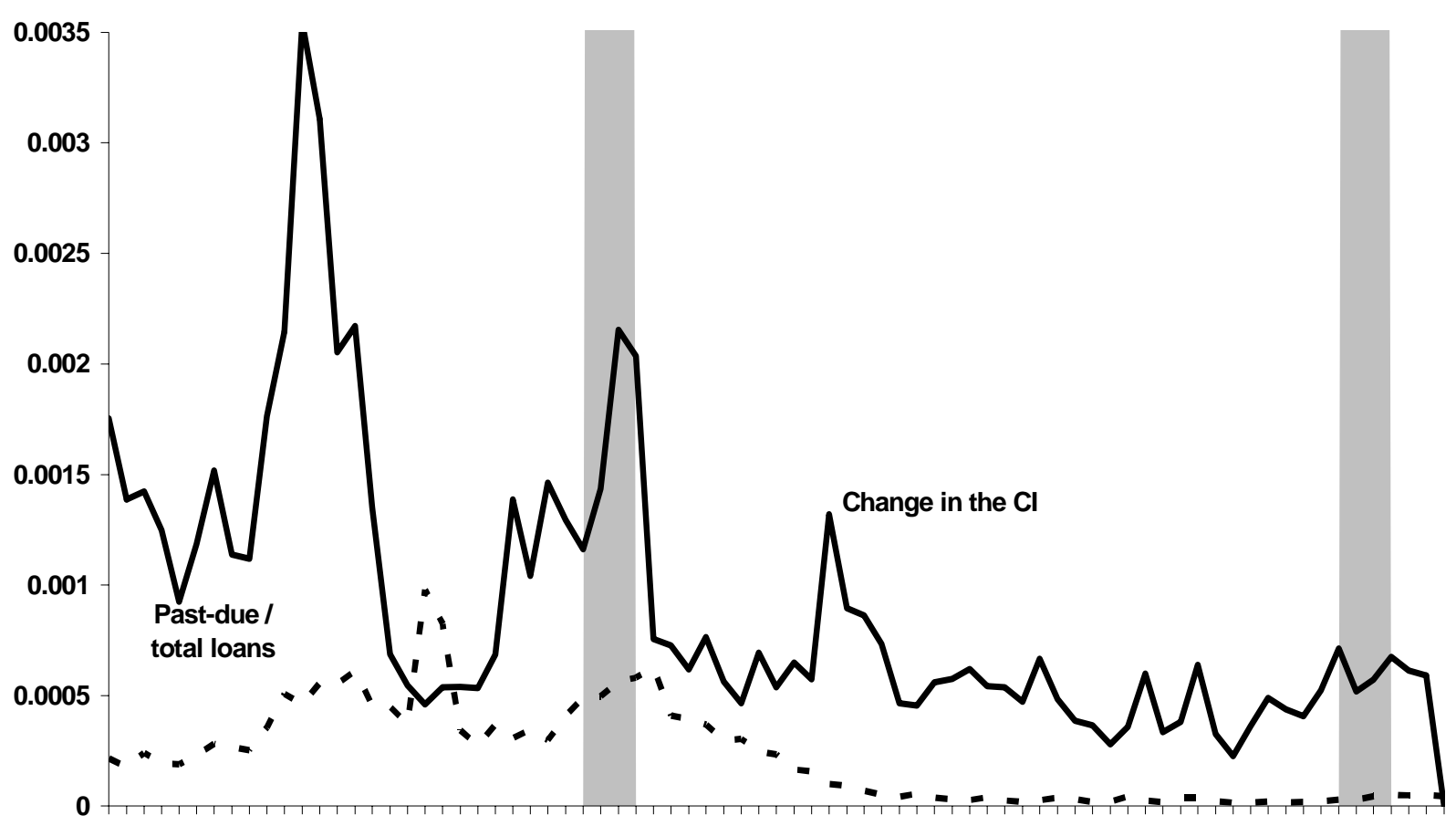

1983198419851986198719881989199019911992199319941995199619971998199920002001 200؛ 


\section{Table 1.}

\section{Summary Statistics of Banking Variables}

Sample Period - Q3.1983 to Q3.2002

Number of Observations: 814,931

Number of Banks: 17,647

\begin{tabular}{l|ccccccc}
\multicolumn{1}{c}{} & Mean & Median & 25 th Pctl & 75th Pctl & Std Dev & Min & Max \\
\hline $\log$ (Assets) & 11.052 & 10.886 & 10.197 & 11.659 & 1.307 & 7.077 & 20.224 \\
Assets (\$000s) & $\$ 425,114$ & $\$ 53,398$ & $\$ 25,275$ & $\$ 115,684$ & $\$ 5,683,578$ & $\$ 1,184$ & $\$ 607,000,000$ \\
Non-Performing / Total Loans & 0.036 & 0.028 & 0.014 & 0.048 & 0.033 & 0.000 & 0.761 \\
Consumer / Total Loans & 0.199 & 0.147 & 0.09 & 0.225 & 0.129 & 0.000 & 0.500 \\
C\&I / Total Loans & 0.201 & 0.171 & 0.107 & 0.261 & 0.132 & 0.000 & 1.000 \\
Residential RE / Total Loans & 0.259 & 0.239 & 0.136 & 0.357 & 0.159 & 0.000 & 1.000 \\
Non-residetial RE / Total Loans & 0.232 & 0.214 & 0.135 & 0.308 & 0.135 & 0.000 & 1.000
\end{tabular}


Table 2. Granger Causality Tests

Bank Performance and Economic Growth by State and Variance of Bank Peformance and Economic Growth Across States

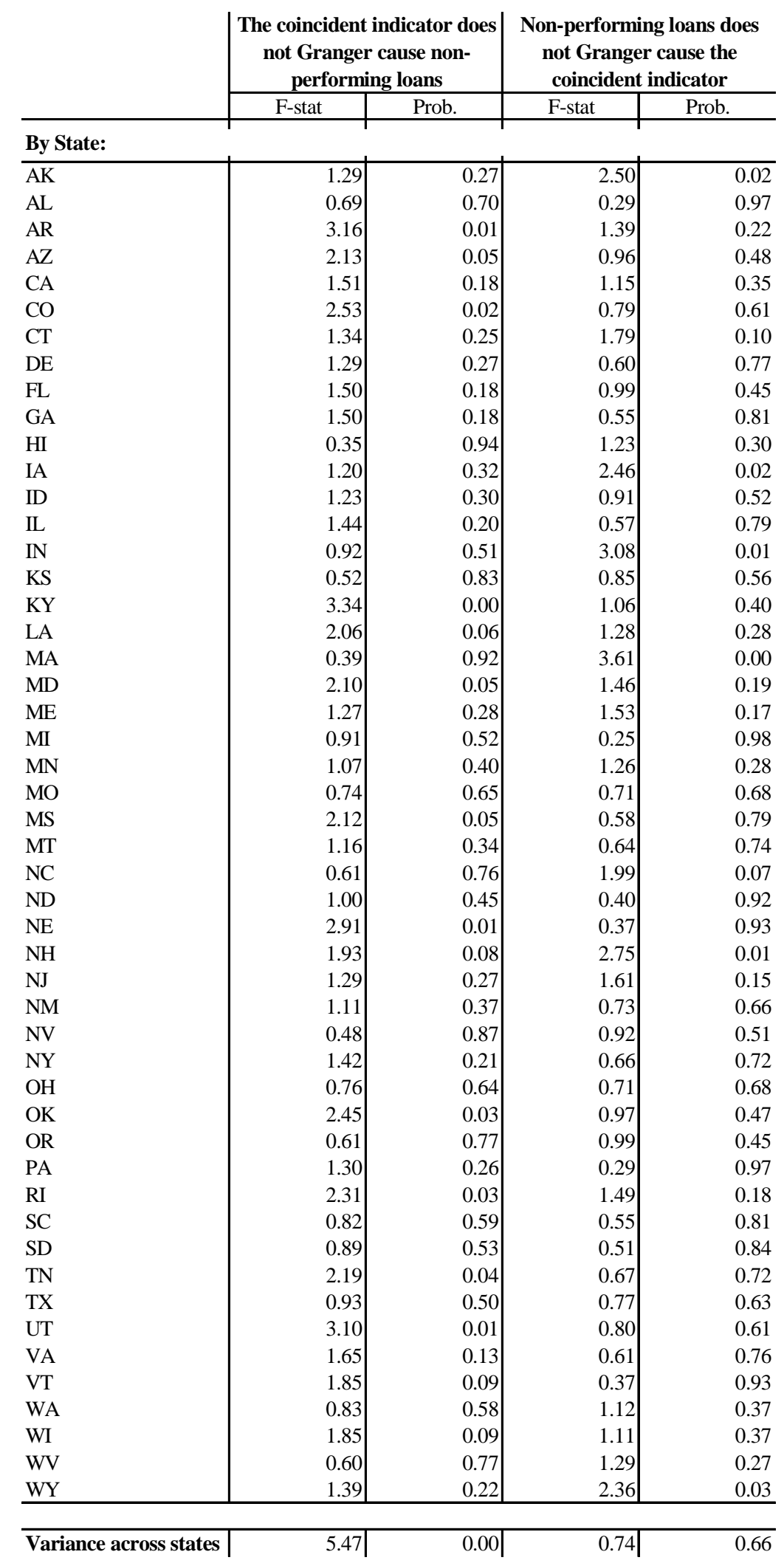


Table 3. Non-Performing Loans to Total Loans

All banks, 1983:Q3 - 2002:Q3

\begin{tabular}{|c|c|c|c|c|c|c|c|c|c|c|}
\hline & \multicolumn{2}{|c|}{ (i) } & \multicolumn{2}{|c|}{ (ii) } & \multicolumn{2}{|c|}{ (iii) } & \multicolumn{2}{|c|}{ (iv) } & \multicolumn{2}{|c|}{ (v) } \\
\hline & coeff. & t-stat. & coeff. & t-stat. & coeff. & t-stat. & coeff. & t-stat. & coeff. & t-stat. \\
\hline $\log$ (Assets) & -0.0007 & -25.11 & -0.0006 & -19.56 & -0.0006 & -19.62 & -0.0007 & -26.11 & -0.0006 & -19.49 \\
\hline Consumer / Total Loans & 0.0016 & 4.37 & 0.0006 & 1.52 & 0.0006 & 1.70 & 0.0022 & 6.09 & 0.0013 & 2.41 \\
\hline C\&I / Total Loans & 0.0048 & 13.98 & 0.0038 & 10.80 & 0.0037 & 10.68 & 0.0048 & 13.69 & 0.0065 & 13.03 \\
\hline Residential Real Estate / Total Loans & -0.0041 & -15.01 & -0.0031 & -11.01 & -0.0031 & -11.11 & -0.0046 & -16.56 & -0.0026 & -6.94 \\
\hline Non-residential / Total Loans & -0.0032 & -9.51 & -0.0020 & -5.72 & -0.0020 & -5.90 & 0.0039 & -11.55 & -0.0011 & -2.37 \\
\hline (Non-Performing / Total Loans) $_{\mathrm{t}-1}$ & 0.8316 & 428.18 & 0.8199 & 397.17 & 0.8196 & 396.99 & 0.8301 & 425.76 & 0.8195 & 396.95 \\
\hline GDP Growth $_{\mathrm{t}-1}$ & & & 0.0168 & 16.67 & 0.0198 & 19.17 & & & 0.0197 & 19.05 \\
\hline House Price Index Growth ${ }_{t-1}$ & & & -0.0029 & -9.96 & -0.0028 & -9.58 & & & -0.0028 & -9.76 \\
\hline Personal Income Growth ${ }_{t-1}$ & & & -0.0061 & -9.98 & -0.0048 & -7.87 & & & -0.0048 & -7.72 \\
\hline Employment Growth $_{\mathrm{t}-1}$ & & & -0.0442 & -34.35 & -0.0276 & -14.49 & & & -0.0270 & -14.00 \\
\hline Unemployment Rate $_{\mathrm{t}-1}$ & & & 0.0008 & 44.23 & 0.0009 & 44.69 & & & 0.0008 & 43.95 \\
\hline Coincident Indicator Growth ${ }_{\mathrm{t}-1}$ & & & & & -0.0174 & -12.68 & -0.0281 & -36.25 & 0.0128 & 2.49 \\
\hline $\mathrm{CI}_{\mathrm{t}-1} \times$ Residential Real Estate / Total Loans & & & & & & & & & -0.0164 & -2.82 \\
\hline $\mathrm{CI}_{\mathrm{t}-1} \times$ Non-residential / Total Loans & & & & & & & & & -0.0288 & -3.75 \\
\hline $\mathrm{CI}_{\mathrm{t}-1} \times$ Consumer / Total Loans & & & & & & & & & -0.0163 & -1.99 \\
\hline $\mathrm{CI}_{\mathrm{t}-1} \times \mathrm{C} \& \mathrm{I} /$ Total Loans & & & & & & & & & -0.0779 & -9.60 \\
\hline Constant & 0.0219 & 8.26 & 0.0131 & 5.20 & 0.0126 & 5.05 & 0.0226 & 8.65 & 0.0111 & 4.55 \\
\hline F-value & 5,148 & & 5,730 & & 5,657 & & 5,042 & & 5,356 & \\
\hline Adj. R-square & 0.7014 & & 0.7038 & & 0.7039 & & 0.7020 & & 0.7039 & \\
\hline Number of Obs. & 793,698 & & 793,698 & & 793,698 & & 793,698 & & 793,698 & \\
\hline
\end{tabular}


Table 4. Non-Performing Loans to Total Loans

Interstate Banks, 1983:Q3 - 2002:Q3

\begin{tabular}{|c|c|c|c|c|c|c|c|c|c|c|}
\hline & \multicolumn{2}{|c|}{ (i) } & \multicolumn{2}{|c|}{ (ii) } & \multicolumn{2}{|c|}{ (iii) } & \multicolumn{2}{|c|}{ (iv) } & \multicolumn{2}{|c|}{$(\mathbf{v})$} \\
\hline & coeff. & t-stat. & coeff. & t-stat. & coeff. & t-stat. & coeff. & t-stat. & coeff. & t-stat. \\
\hline $\log$ (Assets) ${ }_{t-4}$ & -0.0004 & -3.03 & -0.0006 & -4 & -0.0006 & -4.04 & -0.0005 & -3.32 & -0.0006 & -3.97 \\
\hline (Consumer / Total Loans) $)_{\mathrm{t}-4}$ & -0.0014 & -0.4 & 0 & -0.01 & -0.0002 & -0.05 & -0.0013 & -0.36 & -0.0047 & -1.02 \\
\hline$(\mathrm{C} \& \mathrm{I} / \text { Total Loans })_{\mathrm{t}-4}$ & 0.0009 & 0.26 & 0.0001 & 0.03 & 0 & 0.01 & 0.0003 & 0.1 & 0.0026 & 0.5 \\
\hline 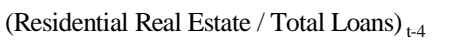 & -0.0086 & -2.9 & -0.0112 & -3.64 & -0.0111 & -3.61 & -0.0095 & -3.16 & -0.0103 & -2.41 \\
\hline 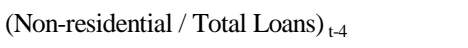 & -0.0021 & -0.69 & -0.0046 & -1.41 & -0.0049 & -1.51 & -0.0032 & -1.05 & -0.0041 & -0.88 \\
\hline (Non-Performing / Total Loans) t -4 & 0.6434 & 25.68 & 0.6422 & 23.44 & 0.6409 & 23.43 & 0.633 & 25.91 & 0.6401 & 23.47 \\
\hline House Price Index Growth ${ }_{t-4}$ & & & -0.0146 & -3.58 & -0.0132 & -3.26 & & & -0.0129 & -3.16 \\
\hline Personal Income Growth $\mathrm{t}_{\mathrm{t}-4}$ & & & 0.0003 & 0.07 & 0.0032 & 0.84 & & & 0.0037 & 0.96 \\
\hline Employment Growth ${ }_{t-4}$ & & & -0.0649 & -6.96 & 0.0009 & 0.08 & & & 0.0036 & 0.31 \\
\hline Unemployment Rate $_{\mathrm{t}-4}$ & & & -0.0009 & -3.24 & -0.0009 & -3.34 & & & -0.0009 & -3.39 \\
\hline Coincident Indicator Growth $\mathrm{t}_{\mathrm{t}-4}$ & & & & & -0.058 & -5.33 & -0.0541 & -7.19 & -0.0495 & -0.64 \\
\hline $\mathrm{CI}_{\mathrm{t}-4} \times$ Residential Real Estate / Total Loans & & & & & & & & & -0.0247 & -0.32 \\
\hline $\mathrm{CI}_{\mathrm{t}-4} \mathrm{x}$ Non-residential / Total Loans & & & & & & & & & -0.0233 & -0.26 \\
\hline $\mathrm{CI}_{\mathrm{t}-4} \times$ Consumer / Total Loans & & & & & & & & & 0.1555 & 1.69 \\
\hline $\mathrm{CI}_{\mathrm{t}-4} \times \mathrm{C} \& \mathrm{I} /$ Total Loans & & & & & & & & & -0.0851 & -0.74 \\
\hline Constant & 0.0211 & 5.98 & 0.033 & 7.7 & 0.0323 & 7.54 & 0.0229 & 6.43 & 0.0318 & 5.99 \\
\hline \multicolumn{11}{|l|}{ F-value } \\
\hline Adj. R-square & 0.5325 & & 0.538 & & 0.5401 & & 0.5378 & & 0.541 & \\
\hline Number of Obs. & 18,267 & & 18,267 & & 18,267 & & 18,267 & & 18,267 & \\
\hline
\end{tabular}

*Robust standard errors computed using Newey-West. 
Table 5. Non-Performing Loans to Total Loans Intrastate Banks, 1983:Q3 - 2002:Q3

\begin{tabular}{|c|c|c|c|c|c|c|c|c|c|c|}
\hline & \multicolumn{2}{|c|}{ (i) } & \multicolumn{2}{|c|}{ (ii) } & \multicolumn{2}{|c|}{ ( iii ) } & \multicolumn{2}{|c|}{ (iv) } & \multicolumn{2}{|c|}{$(\mathrm{v})$} \\
\hline & coeff. & t-stat. & coeff. & t-stat. & coeff. & t-stat. & coeff. & t-stat. & coeff. & t-stat. \\
\hline $\log$ (Assets) $)_{t-4}$ & -0.001 & -17.38 & -0.0008 & -13.91 & -0.0008 & -14.04 & -0.001 & -18.12 & -0.0008 & -13.88 \\
\hline 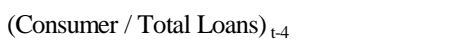 & -0.0005 & -0.63 & -0.0018 & -2.1 & -0.0015 & -1.81 & 0.0006 & 0.69 & -0.0023 & -2.15 \\
\hline$(\mathrm{C} \& \mathrm{I} / \text { Total Loans })_{\mathrm{t}-4}$ & 0.0074 & 10.1 & 0.0063 & 8.5 & 0.0062 & 8.41 & 0.0072 & 9.88 & 0.0106 & 11.09 \\
\hline (Residential Real Estate / Total Loans) $_{\mathrm{t}-4}$ & -0.0104 & -17.49 & -0.0094 & -15.4 & -0.0095 & -15.59 & -0.0112 & -18.52 & -0.008 & -10.06 \\
\hline 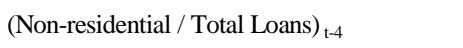 & -0.01 & -13.03 & -0.0079 & -10.61 & -0.0081 & -10.84 & -0.0105 & -14.16 & -0.0039 & -4.02 \\
\hline (Non-Performing / Total Loans) ${ }_{t-4}$ & 0.6717 & 193.05 & 0.6547 & 178.92 & 0.654 & 178.4 & 0.6694 & 191 & 0.6539 & 177.66 \\
\hline House Price Index Growth ${ }_{\mathrm{t}-4}$ & & & -0.0116 & -15.1 & -0.0109 & -14.36 & & & -0.0108 & -14.23 \\
\hline Personal Income Growth $\mathrm{t}_{\mathrm{t}-4}$ & & & 0.0103 & 13.25 & 0.0144 & 17.93 & & & 0.0144 & 17.98 \\
\hline Employment Growth $\mathrm{t}-4_{4}$ & & & -0.0558 & -24.93 & -0.0078 & -3.25 & & & -0.0075 & -3.14 \\
\hline Unemployment Rate $_{\mathrm{t}-4}$ & & & 0.0012 & 28.19 & 0.0013 & 29.64 & & & 0.0012 & 28.43 \\
\hline Coincident Indicator Growth ${ }_{t-4}$ & & & & & -0.0469 & -20.52 & -0.0439 & -22.76 & 0.0198 & 1.66 \\
\hline $\mathrm{CI}_{\mathrm{t}-4} \mathrm{x}$ Residential Real Estate / Total Loans & & & & & & & & & -0.047 & -3.43 \\
\hline $\mathrm{CI}_{\mathrm{t}-4} \mathrm{x}$ Non-residential / Total Loans & & & & & & & & & -0.135 & -7.87 \\
\hline $\mathrm{CI}_{\mathrm{t}-4} \times$ Consumer / Total Loans & & & & & & & & & 0.0254 & 1.35 \\
\hline $\mathrm{CI}_{\mathrm{t}-4} \mathrm{x}$ C\&I / Total Loans & & & & & & & & & -0.1367 & -7.79 \\
\hline Constant & 0.0403 & 6.18 & 0.0295 & 4.64 & 0.0281 & 4.47 & 0.0413 & 6.38 & 0.0253 & 4.07 \\
\hline F-value & 1,079 & & 1,129 & & 1,116 & & 1,076 & & 1,061 & \\
\hline Adj. R-square & 0.4854 & & 0.4903 & & 0.4909 & & 0.4871 & & 0.4914 & \\
\hline Number of Obs. & 586,700 & & 586,700 & & 586,700 & & 586,700 & & 586,700 & \\
\hline
\end{tabular}

*Robust standard errors computed using Newey-West. 
Table 6. Spearman rank correlations

between actual and forecasted state-level problem loan ratios

\begin{tabular}{c|c|c|c|c} 
Quarter & (i) & (ii) & (iii) & (iv) \\
\hline 1989.Q1 & 0.4748 & 0.5257 & 0.5679 & 0.4708 \\
1989.Q2 & 0.4565 & 0.5404 & 0.6031 & 0.4584 \\
1989.Q3 & 0.4119 & 0.4747 & 0.5314 & 0.4159 \\
1989.Q4 & 0.3683 & 0.5177 & 0.6064 & 0.3778 \\
\hline 1995.Q1 & 0.5797 & 0.4405 & 0.4859 & 0.6378 \\
1995.Q2 & 0.7006 & 0.5674 & 0.6078 & 0.7703 \\
1995.Q3 & 0.8237 & 0.6873 & 0.7149 & 0.8442 \\
1995.Q4 & 0.7182 & 0.4322 & 0.4955 & 0.7417 \\
\hline 2002.Q1 & 0.3195 & 0.2993 & 0.4253 & 0.4478 \\
2002.Q2 & 0.2986 & 0.3125 & 0.3687 & 0.4012 \\
\hline
\end{tabular}

Note: All Spearman rank correlations are statistically significant at the 5\% level. 